\title{
Zika virus: a new pandemic threat
}

\author{
Ahmed A Al-Qahtani ${ }^{1,2}$, Nyla Nazir ${ }^{1}$, Mashael R Al-Anazi ${ }^{1}$, Salvatore Rubino ${ }^{1,3}$, Mohammed N Al-Ahdal ${ }^{1,2,3}$ \\ ${ }^{1}$ Department of Infection and Immunity, Research Center, King Faisal Specialist Hospital and Research Center, \\ Riyadh, Saudi Arabia \\ ${ }^{2}$ Department of Microbiology and Immunology, Alfaisal University School of Medicine, Riyadh, Saudi Arabia \\ ${ }^{3}$ Biomedical Sciences Department, University of Sassari, Sassari, Italy
}

\begin{abstract}
Zika virus (ZIKV) is an emerging arbovirus of the Flaviviridae family and is related to dengue, Chikungunya, West Nile, yellow fever, and Japanese encephalitis viruses. ZIKV was first discovered in Uganda in 1947. Different species of mosquito from the Aedes genus, mainly $A$. aegypti and $A$. albopictus are the vectors responsible for ZIKV infection in humans. It is also reported that ZIKV is transmitted congenitally, sexually, and through blood donation. Until recently, ZIKV outbreaks were sporadic and self-limiting. The first large epidemic was reported from Yap Island in 2007 followed by an outbreak of Zika fever in French Polynesia in 2013. Brazil is the epicenter of the current ZIKV epidemic which is rapidly spreading across the Americas. ZIKV infection remained relatively less studied in view of its low case numbers, and low clinical impact relative to other arboviruses. However, all this is set to change with its rapid spread in the Western hemisphere and suspected complications particularly microcephaly in newborn babies with ZIKV infected mothers. ZIKV is expected to substantially add to both shortterm and long-term economic burden of the effected countries. Due to the large number of people travelling across the borders and some reported cases of transmission of ZIKV via contaminated blood, screening and identification of asymptomatic infected individuals are important.
\end{abstract}

Key words: Zika virus; Flavivirus; microcephaly; mosquito; Aedes.

J Infect Dev Ctries 2016; 10(3):201-207. doi:10.3855/jidc.8350

(Received 08 March 2016 - Accepted 22 March 2016)

Copyright (C) 2016 Al-Qahtani et al. This is an open-access article distributed under the Creative Commons Attribution License, which permits unrestricted use, distribution, and reproduction in any medium, provided the original work is properly cited.

\section{Introduction}

The recent outbreak of Zika virus (ZIKV) through Latin America and the Caribbean [1,2] has drawn the attention of the world towards this relatively unknown and unstudied virus, particularly for its association with pregnancy and the related increased number of newborn presenting microcephaly reported in Brazil [3]. Furthermore, a major concern is related to the upcoming Olympic games in Brazil in August this year; for this reason health information for travelling was issued by Centres for Disease Control and Prevention (CDC) [4] as well as for religious mass gatherings such as Umrah, taking place between June and September and Hajj in September when more than 7 million pilgrims will reach Saudi Arabia from all over the world including Latin America [5].

In February 2016, the World Health Organization (WHO) declared ZIKV a Global Emergency of Public Health Concern. WHO Director-General summarized the outcome of the Emergency Committee regarding clusters of microcephaly and Guillain-Barré syndrome [6].
Although, it belongs to the group of viruses that includes dengue and chikungunya, ZIKV seems to be associated with more severe health consequences. ZIKV can infect several different species of mosquito that belong to the genus Aedes and it is known to be transmitted by two species of mosquito in this genus, namely $A$. aegypti and A. albopictus. The potential for autochthonous transmission in countries where Aedes vectors are present is evident and is a major concern given to the speed at which the disease has recently spread.

ZIKV was discovered in 1947 in a rhesus monkey found in Uganda's Zika forest during a monitoring program for sylvatic yellow fever [7]. The first case of human infection was reported in 1952 in Uganda and Tanzania [8], while the virus was isolated two years later in a young girl from eastern Nigeria during a jaundice outbreak [9]. The virus was later isolated from humans in South East Asia [10-13]. Until 2007, human ZIKV infections were limited and sporadic, without any major outbreaks. The first large epidemic was reported in 2007 on the Pacific Island of Yap with nearly $75 \%$ of 
the population being infected with the virus [14]. Further, an outbreak of Zika fever in 2013 was reported in French Polynesia, in addition to several cases of ZIKV infection in New Caledonia, Easter Island and the Cook Islands, indicating a rapid spreading of the virus in the Pacific area. The current ZIKV epidemic which is fast spreading across the Americas, started in Brazil, with first confirmed case reported in May 2015. Until March $6^{\text {th }}, 2016$, the disease was reported at a local level in 31 countries and territories of the Americas, 4 in Oceania and Pacific Islands and Capo Verde in Africa and in several countries out of the American continent in people travelling in these areas [15]. A summary on Zika infection, continent by continent from the early time of its discovery in 1947 until the beginning of February 2016 was presented in the WHO report [16]. Also, after the discovery of the sexual transmission of the virus in one case in Texas, USA [17] and the fact that ZIKV can be easily detected in human semen [18], CDC published the recommendations for preventing sexual transmission of ZIKV [19].

\section{Classification and taxonomy}

ZIKV is an arbovirus member of the Spondweni serocomplex within the genus Flavivirus, family Flaviviridae. Other flaviviruses (members of that genus) include Yellow fever virus, Dengue virus (DENV), Japanese encephalitis virus (JEV), Tick-borne encephalitis virus (TBEV), West Nile virus (WNV), St. Louis encephalitis virus and Murray valley encephalitis virus (MVEV). Similar to other members of the Flavivirus genus, ZIKV contains a positive singlestranded genomic RNA, encoding a polyprotein that is processed into three structural proteins, the capsid (C), the precursor of membrane (prM) and the envelope (E), and seven nonstructural proteins NS1 to NS5 [20].

\section{Transmission}

ZIKV is transmitted to people through the bite of an infected mosquito from the Aedes genus, mainly $A$. aegypti and A. albopictus. Both species are known to thrive in proximity to people, though $A$. aegypti often breeds very close to or even inside home. In May 2015, Brazil confirmed autochthonous transmission (the spread of infection from one individual to another in the same area) in the States of Bahia and Rio Grande do Norte [21]. As with any blood-borne pathogen, there have been reports of transmission via contaminated blood, by transfusion [22]. Another, relatively new, route of transmission of ZIKV is through sexual contact [23,24]. Although in 2014 Besnard et al., [25] have reported perinatal transmission from mothers to newborns, this mode of transmission has been the focus in recent epidemic in Brazil due to its dire effects on fetal development. It has been reported that mother-tochild transmission can occur, most probably transplacental or during the delivery in infected mothers [25]. However, many questions remain to be answered due to lack of confirmatory evidence. Such questions include the calculation of the rate of vertical transmission, by which mechanism the virus is able to target the neurological system of fetuses, at which time of pregnancy the virus exerts its pathological effect and the exact biological mechanism through which ZIKV penetrates the placental barrier. However, the transmission cycle of the virus is mainly from reservoir host to mosquito to reservoir host with an incubation period of 2-5 days in host and 5-7 days in mosquito.

\section{Pathogenesis}

In comparison to other similar viruses, ZIKV has received far less attention. As a result, pathogenesis of ZIKV infection remains poorly understood. Mosquitomediated transmission of ZIKV is initiated when a blood-feeding female Aedes mosquito injects the virus into the human skin followed by viral replication initially in dendritic cells near the site of inoculation and subsequent spreading to lymph nodes and the bloodstream [26]. ZIKV infection of epidermal cells induces the appearance of cytoplasmic vacuolation indicative of cell apoptosis [27]. It has been suggested that flaviviral replication occurs in cellular cytoplasm, although one study reported the presence of ZIKV antigens in infected cell nuclei [28]. Infectious ZIKV has been detected in human blood as early as the day of illness onset or as late as 11 days after onset [28]. The incubation period ZIKV infection has been suggested to be 3-12 days. The outcome of viral infection is determined by a competition between viral replication and the host immune response.

\section{Clinical Manifestations}

About 20-25\% of people infected with ZIKV develop symptoms which usually include rash, fever, arthralgia and conjunctivitis as the most common symptoms and headache, vomiting and oedema in a minority [29]. Moreover, ZIKV infection has been suggested to be associated with more severe neurological complications including microcephaly, a serious birth defect characterized by babies with small heads and incomplete brain development born from infected mothers. Additionally, other fetal complications recently reported include fetal death, placental insufficiency, fetal growth restriction and 
CNS injury [30]. Another rare complication is GuillainBarre syndrome (GBS) a disorder where a person's own immune system damages the nerve cells, leading to muscle weakness. However, more work is warranted to establish the exact link and clinical manifestation between and ZIKV and GBS. Brazil, with ZIKV epidemic, has observed a significant increase in microcephaly cases in 2015 as compared to previous years. However, scientific evidence linking neurological disorders with ZIKV infection is still lacking.

\section{Diagnosis}

Diagnosis of Zika infection is mostly based on clinical symptoms and epidemiological circumstances. However, several laboratory diagnostic tests are available:

- Nucleic acid detection by reverse transcriptasepolymerase chain reaction (RT-PCR) targeting the viral genome [31].

- Serological detection using ELISA has been developed at the Arboviral Diagnostic and Reference Laboratory of the Centers for Disease Control and Prevention (Ft. Collins, CO, USA) to detect IgM to ZIKV only after five days. Diagnosis by serology can be difficult as the virus can crossreact with other flaviviruses such as dengue, West Nile and yellow fever.

- Nucleic acid amplification test (NAT) for detection of viral RNA can also be performed.

- The plaque reduction neutralization assay is also used for diagnosis. Although this assay generally has improved specificity over immunoassays, it may still yield cross-reactive results in secondary flavivirus infections.

Out of the abovementioned list of assays for the diagnosis of ZIKV, molecular methods show great promise for rapid and cost-effective methods as they have high sensitivity and specificity for the virus [31]. For such molecular tests, a non-invasive method, using saliva as a source of ZIKV RNA, can be readily used for the detection of ZIKV [32].

\section{Treatment}

There is no vaccine or specific treatment for ZIKV infection. To date, ZIKV infection has been mild and self-limited, with patients requiring help to alleviate symptoms. However, all medical management procedures should be applied to suspected cases as recommended by WHO [33]. Also, there is an ethical obstacle in targeting pregnant women for the development of vaccine against ZIKV. It is highly recommended to develop an acceptable ethical agenda that can be globally applied to target pregnant women [34].

\section{Recent events and outbreak}

The current epidemic in Brazil has been suggested to begin with the arrival of the ZIKV from French Polynesia during the 2014 FIFA World Cup tournament, or shortly after, based on DNA analysis of the virus [35]. Also, another sport event, the Va'a World Sprint Championship canoe race, was held in Rio de Janeiro in Brazil in August 2014. Four Pacific countries (French Polynesia, New Caledonia, Cook Islands, and Easter Island) in which ZIKV circulated during 2014 had teams engaged in this contest in several categories. These data combined with phylogenetic studies suggest that ZIKV introduction in Brazil may have been a consequence of this event [35]. Additionally, in May 2015, ZIKV was first confirmed as the cause of an outbreak of a dengue-like disease in northern and eastern Brazil. In several districts of Brazil, unknown reports of flu-like symptoms and rashes were identified as ZIKV infection by RT-PCR technique. By October 2015, 2,700 babies in Brazil were born with microcephaly suggested to be linked to ZIKV infection, marking a dramatic increase over the 150 microcephaly cases recorded there in 2014. A few weeks later, Brazil declared a state of emergency. Brazil is now considered the epicenter of ZIKV outbreak, which coincides with at least 4,000 reports of babies born with microcephaly just since last October [36]. Around a third of these were reported in the state of Pernambuco. The virus was reported to have reached Colombia in October and other countries in Latin America including the Caribbean in November and December. Confirmed cases have now been reported in most of South and Central America, and the Caribbean. ZIKV infections have recently been confirmed among nine Canadians who had travelled to areas most affected by the virus [37]. Two cases of ZIKV have been confirmed in Australia [38] and two in Ireland [39]. In the U.S. States and its territories, 36 cases of travel-associated and 9 cases of locally acquired cases of ZIKV infection have been confirmed [40]. On $2^{\text {nd }}$ February 2016, the first known case of ZIKV with sexual transmission in the United States was reported in Texas from an infected person returning from Venezuela. Transmission is currently active in at least 30 countries across the Americas, Pacific Islands and Cape Verde, while ZIKV has also appeared in several other European countries after tourists were infected abroad. WHO estimates that the virus could infect as 
many as four million people in the coming months and recently declared the ZIKV outbreak as "Public Health Emergency of International Concern”.

\section{WHO and CDC recommendation}

Fully acknowledging the threat posed by ZIKV epidemic, the WHO has declared a global health emergency for just the fourth time in the Agency's history. The WHO convened the first meeting of the Emergency Committee (EC) under the International Health Regulations (2005) (IHR 2005) regarding clusters of microcephaly cases and other neurologic disorders in some areas affected by ZIKV on 1 February 2016. The committee released a number of recommendations for countries facing a ZIKV outbreak, including new travel measures.

\section{Possible mechanisms for brain damage}

Until recently, ZIKV infection was mostly asymptomatic or associated with only mild disease [14]. However, the outbreak of Zika infection in Brazil in May 2015 drew attention to the simultaneous increase in microcephaly, a neurological disorder in infants. Brazil reported around 4,000 cases of microcephaly since the Zika epidemic whereas less than 200 cases per year was the norm in previous years [36]. Although, there is no scientific proof of an exact link between ZIKV and microcephaly, the dramatic increase in babies born with microcephaly to women who may have had the ZIKV infection demands thorough investigation.

The term microcephaly literally means "small head." Babies born with microcephaly have head circumference much smaller than that of the average circumference of a baby's head of the same age, gender, and gestational age. If a pregnant woman develops ZIKV infection, the virus can cross the placenta and infect the baby. If the baby is in its critical stages of brain development, the infection can result in poor development of the fetal brain and being born with microcephaly.

The impact on the fetus is more severe if the ZIKV infection is present during earlier stages of pregnancy possibly resulting in profound abnormalities and cognitive deficits [41, 42]. There is very limited knowledge about the possible mechanisms of how ZIKV infection leads to fetal brain damage. A clue may be provided by other viruses associated with microcephaly. Among the viruses, human cytomegaloviruses are strongly associated with a large number of cases of microcephaly. Teissier et al. (2014) [43] studied neurologic morbidity associated with congenital cytomegalovirus (CMV) infection and suggested that the virus attacks stem cells during early brain development while also causing the general destruction of other brain tissues [43]. This early loss of stem cells may keep a fetal brain from forming the correct architecture leading to microcephaly. A recent study by Mlakar et al. (2016) [44] gave further insight into fetal brain damage by ZIKV infection [44]. This group studied the case of a pregnant European woman in whom a syndrome compatible with ZIKV infection developed at 13 weeks of gestation while she was working in Northeastern Brazil. She subsequently returned to Europe, where ultrasonographic examinations performed late in the pregnancy showed symptoms of microcephaly. After approval by national and hospital ethics boards, the patient chose a latepregnancy termination. The autopsy report showed that the fetal brain was grossly damaged. Further it was reported that the fetus had a very small brain (weight, $84 \mathrm{~g}$ ), with a complete absence of cerebral gyri. Other findings in the autopsy included severe dilation of both cerebral lateral ventricles, dystrophic calcifications throughout the cerebral cortex, and hypoplasia of the brain stem and spinal cord, including Wallerian degeneration of the long descending spinal tracts [44]. A large amount of viral genomic RNA similar to that of other recent ZIKV isolates was detected in the brain tissues only. Such reports provide strong evidence that ZIKV infection is linked to microcephaly, though further investigations are required to elucidate the exact mechanisms.

\section{Prevention}

ZIKV is transmitted primarily to humans through the bite of an infected Aedes species mosquito, which can be considered as a vulnerable point for ZIKV transmission. Unfortunately, mosquito-control efforts have failed to curtail the spread of many similar pathogens, including dengue and chikungunya viruses, which are carried by the same Aedes species and are spreading in the same communities currently affected by the ZIKV. The standard old practices of using insecticides and removing the standing water where mosquitoes breed have not been sufficiently effective to control the mosquito vectors. Brazil has started a novel approach to fight the spread ZIKV: genetically modified mosquitoes. These genetically modified Aedes mosquitoes have been created by a Britain-based Company, Oxitec. These mosquitoes contain an inserted gene producing a protein called tetracycline repressible activator variant (tTAV), which ties up the cell's machinery and prevents the expression of other 
genes key to survival, leading to early death of insects [45]. The pest population control is achieved by releasing mature males carrying the self-destructing gene into the wild to mate with females. Offspring who inherit the gene will die, causing the mosquito population to drop drastically and thereby, reducing the spread of disease. In April 2015, Oxitec started releasing its so-called "self-limiting" mosquitoes in Piracicaba, a Brazilian city and reported an 82 percent reduction in wild larvae by the end of the calendar year (http://www.oxitec.com/oxitec-vector-controlsolution-in-brazil-attacking-source-of-zika-virus/).

However, this approach must be applied with great care as genetically engineered mosquitoes could increase the transmissibility of other mosquito-transmitted organisms or result in other unexpected results. Another approach to control Aedes mosquito, using Wolbachia bacterium has been developed at Monash University in Australia. The strategy includes infecting Aedes mosquito with Wolbachia which does not infect Aedes in the natural environment. Once infected, the mosquitoes do not pick up and transmit viruses as easily. Wolbachia bacteria are transmitted to the next generation through eggs and can be sustained in the environment for a long time [46, 47]. However, some concerns remain that using these genetically modified mosquito vectors may cause unintended, negative effects to the ecosystem.

\section{Conspiracy theory}

The ZIKV is spreading fast across the Americas with potentially devastating effects on babies exposed to the virus in utero. The possible association of ZIKV infection with microcephaly has spawned a number of conspiracy theories as to how the virus arose and other potential causes of microcephaly. A group of Argentine doctors claimed that a larvicide and not the mosquitoborne ZIKV was the real cause of rise in microcephaly cases. The Brazilian government has clarified that increased microcephaly cases were also observed in regions where the larvicide, pyriproxyfen, had not been used, in its drinking water. Further, the government asserted that the use of this larvicide was approved by WHO and there was no scientific proof of its association with microcephaly. Another group blames the Oxitec Company stating that the release of the genetically modified mosquitoes in Brazil in 2011 to control spread of dengue fever, is behind the current epidemic of ZIKV. Brazilian health officials and scientists have refuted these claims and emphasized that the genetically modified mosquitoes have been able to reduce the mosquito population in the affected areas.
Another popular misconception spreading across Brazil is that the vaccines for chickenpox and rubella virus are responsible for surge in microcephaly cases. A rather bizarre rumour is that this epidemic is a plot by the global elites to depopulate the world. Due to very little knowledge about ZIKV, an aura of mystery has developed about its origin, spread and consequences. With the lack of scientific explanations, many conspiracy theories about ZIKV have spread explosively. Efforts are required to publicize authentic information about various aspects of ZIKV infection among the populations.

\section{Sources on ZIKV}

Recently, Zika Tracker on a mobile web-based multi-lingual App has been developed using Android or iPhone smart phones to voluntarily report suspected and/or confirmed cases of ZIKV [48]. Also, the following are suggested websites for more information on ZIKV:

WHO | Zika virus: [33]

Zika Virus $\mid$ CDC - Centers for Disease Control and Prevention: [49]

PAHO WHO | Zika virus infection: [50]

Zika virus infection ECDC: [51]

Zika Virus Health Information Resources - SIS Home: [52]

Zika Virus | Medscape: [53].

\section{Acknowledgements}

The support of the Research Center administration at King Faisal Specialist Hospital and Research Center (KFSHRC) is highly appreciated.

\section{References}

1. Heukelbach J, Alencar CH, Kelvin AA, De Oliveira WK, Pamplona de Góes Cavalcanti L (2016) Zika virus outbreak in Brazil. J Infect Dev Ctries 10: 116-120. doi:10.3855/jidc.8217.

2. Rodriguez-Morales AJ (2015) Zika: the new arbovirus threat for Latin America. J Infect Dev Ctries 9: 684-685. doi:10.3855/jidc.7230.

3. Campos GS, Bandeira AC, Sardi SI (2015) Zika Virus Outbreak, Bahia, Brazil. Emerg Infect Dis 21: 1885-1886.

4. Centers for Disease Control and Prevention (CDC) (2016) CDC 24/7 Saving Lives, Protecting People. Available: http://wwwnc.cdc.gov/travel/notices/alert/2016-summerolympics-rio>. Accessed 21 March 2016.

5. Elachola H, Gozzer E, Zhuo J, Memish ZA (2016) A crucial time for public health preparedness: Zika virus and the 2016 Olympics, Umrah, and Hajj. Lancet 387: 630-632.

6. World Health Organization (WHO) (2016) WHO Media centre, $2016 . \quad$ Available: http://www.who.int/mediacentre/news/statements/2016/emerg 
ency-committee-zika-microcephaly/en/. Accessed 21 March 2016.

7. Dick GW, Kitchen SF, Haddow AJ (1952) Zika virus. I. Isolations and serological specificity. Trans R Soc Trop Med Hyg 46: 509-520.

8. Smithburn KC (1952) Neutralizing antibodies against certain recently isolated viruses in the sera of human beings residing in East Africa. J Immunol 69: 223-234.

9. Macnamara FN (1954) Zika virus: a report on three cases of human infection during an epidemic of jaundice in Nigeria. Trans R Soc Trop Med Hyg 48: 139-145.

10. Olson JG, Ksiazek TG, Suhandiman, Triwibowo (1981) Zika virus, a cause of fever in Central Java, Indonesia. Trans R Soc Trop Med Hyg 75: 389-893.

11. Weinbren MP, Williams MC (1958) Zika virus: further isolations in the Zika area, and some studies on the strains isolated. Trans R Soc Trop Med Hyg 52: 263-268.

12. Haddow AJ, Williams MC, Woodall JP, Simpson DI, Goma LK (1964) Twelve isolations of zika virus from Aedes (stegomyia) africanus (Theobald) taken in and above Uganda forest. Bull World Health Organ 31: 57-69.

13. Haddow AD, Schuh AJ, Yasuda CY, Kasper MR, Heang V, Huy R, Guzman H, Tesh RB, Weaver SC (2012) Genetic characterization of Zika virus strains: geographic expansion of the Asian lineage. PLoS Negl Trop Dis 6: e1477.

14. Duffy MR, Chen TH, Hancock WT, Powers AM, Kool JL, Lanciotti RS, Pretrick M, Marfel M, Holzbauer S, Dubray C, Guillaumot L, Griggs A, Bel M, Lambert AJ, Laven J, Kosoy O, Panella A, Biggerstaff BJ, Fischer M, Hayes EB (2009) Zika virus outbreak on Yap Island, Federated States of Micronesia. N Engl J Med 360: 2536-2543.

15. World Health Organization (WHO) (2016) WHO Programmes: Emergencies preparedness, response, 2016. Available: http://www.who.int/csr/don/1-march-2016-zika-stvincent-and-grenadines/en/. Accessed 21 March 2016.

16. World Health Organization (WHO) (2016) WHO Programmes: Emergencies, 2016. Available: http://www.who.int/emergencies/zika-virus/timeline/en/. Accessed 21 March 2016.

17. Dallas County Health and Human Services (HHS) (2016) HHS Public Health Preparedness Update, 2016. Available: https://www.dallascounty.org/department/hhs/documents/Feb ruary2016Newsletter.pdf. Accessed 21 March 2016.

18. Musso D, Roche C, Robin E, Nhan T, Teissier A, CaoLormeau VM (2015) Potential sexual transmission of Zika virus. Emerg Infect Dis 21: 359-361.

19. Oster AM, Brooks JT, Stryker JE, Kachur RE, Mead P, Pesik NT, Petersen LR (2016) Interim Guidelines for Prevention of Sexual Transmission of Zika Virus - United States, 2016. MMWR Morb Mortal Wkly Rep 65: 120-121.

20. Kuno G, Chang GJ, Tsuchiya KR, Karabatsos N, Cropp CB (1998) Phylogeny of the genus Flavivirus. J Virol 72: 73-83.

21. Hennessey M, Fischer M, Staples JE (2016) Zika Virus Spreads to New Areas - Region of the Americas, May 2015January 2016. MMWR Morb Mortal Wkly Rep 65: 55-58.

22. Musso D, Nhan T, Robin E, Roche C, Bierlaire D, Zisou K, Shan Yan A, Cao Lormeau VM, Broult J (2014) Potential for Zika virus transmission through blood transfusion demonstrated during an outbreak in French Polynesia, November 2013 to February 2014. Euro Surveill 19(14).

23. Musso D (2015) Zika Virus Transmission from French Polynesia to Brazil. Emerg Infect Dis 21: 1887.
24. Foy BD, Kobylinski KC, Chilson Foy JL, Blitvich BJ, Travassos da Rosa A, Haddow AD, Lanciotti RS, Tesh RB (2011) Probable non-vector-borne transmission of Zika virus, Colorado, USA. Emerg Infect Dis 17: 880-882.

25. Besnard M, Lastere S, Teissier A, Cao-Lormeau V, Musso D (2014) Evidence of perinatal transmission of Zika virus, French Polynesia, December 2013 and February 2014. Euro Surveill 19 (13).

26. Diamond MS, Shrestha B, Mehlhop E, Sitati E, Engle M (2003) Innate and adaptive immune responses determine protection against disseminated infection by West Nile encephalitis virus. Viral Immunol 16: 259-278.

27. Hamel R, Dejarnac O, Wichit S, Ekchariyawat P, Neyret A, Luplertlop N, Perera Lecoin M, Surasombatpattana P, Talignani L, Thomas F, Cao-Lormeau VM, Choumet V, Briant L, Desprès P, Amara A, Yssel H, Missé D (2015) Biology of Zika Virus Infection in Human Skin Cells. J Virol 89: 88808896.

28. Hayes EB (2009) Zika virus outside Africa. Emerg Infect Dis 15:1347-1350.

29. Heang V, Yasuda CY, Sovann L, Haddow AD, Travassos da Rosa AP, Tesh RB, Kasper MR (2012) Zika virus infection, Cambodia, 2010. Emerg Infect Dis 18: 349-351.

30. Brasil P, Pereira, JP Jr, Raja Gabaglia C, Damasceno L, Wakimoto M, Ribeiro Nogueira RM, Carvalho de Sequeira P, Machado Siqueira A, Abreu de Carvalho LM, Cotrim da Cunha D, Calvet GA, Neves ES, Moreira ME, Rodrigues Baiao AE, Nassar de Carvalho PR, Janzen C, Valderramos SG, Cherry JD, Bispo de Filippis AM, Nielsen-Saines K (2016) Zika Virus Infection in Pregnant Women in Rio de Janeiro - Preliminary Report. N Engl J Med.

31. Faye O, Faye O, Dupressoir A, Weidmann M, Ndiaye M, Alpha Sall A (2008) One-step RT-PCR for detection of Zika virus. J Clin virol 43: 96-101.

32. Musso D, Roche C, Nhan TX, Robin E, Teissier A, CaoLormeau VM (2015) Detection of Zika virus in saliva. J Clin Virol 68: 53-55.

33. World Health Organization (WHO) (2016) WHO Fact sheets: Media Centre, $2016 . \quad$ Available: http://www.who.int/mediacentre/factsheets/zika/en/. Accessed 21 March 2016.

34. Omer SB, Beigi RH (2016) Pregnancy in the Time of Zika: Addressing Barriers for Developing Vaccines and Other Measures for Pregnant Women. JAMA 2016 Feb 24. doi: 10.1001/jama.2016.2237. [Epub ahead of print].

35. Zanluca C, Melo VC, Mosimann AL, Santos GI, Santos CN, Luz K (2015) First report of autochthonous transmission of Zika virus in Brazil. Mem Inst Oswaldo Cruz 110: 569-572.

36. Schuler-Faccini L, Ribeiro EM, Feitosa IM, Horovitz DD, Cavalcanti DP, Pessoa A, Doriqui MJ, Neri JI, Neto JM, Wanderley HY, Cernach M, El-Husny AS, Pone MV, Serao CL, Sanseverino MT (2016) Brazilian Medical Genetics Society-Zika Embryopathy Task Force. Possible Association between Zika Virus Infection and Microcephaly-Brazil, 2015. MMWR Morb Mortal Wkly Rep 65: 59-62.

37. CBC News. CBC News: Politics, 2016. Available: http://www.cbc.ca/news/politics/zika-virus-canadians1.3452016. Accessed 21 March 2016.

38. BBC News. BBC News: World-Australia, 2016. Available: http://www.bbc.com/news/world-australia-35479165. Accessed 21 March 2016. 
39. BBC News. BBC News: World-Europe, 2016. Available: http://www.bbc.com/news/world-europe-35480562. Accessed 21 March 2016.

40. Centers for Disease Control and Prevention (2016) CDC 24/7: Saving Lives, Protecting People, 2016. Available: http://www.cdc.gov/zika/geo/united-states.html. Accessed 21 March 2016.

41. Carod-Artal FJ (2016) Epidemiology and neurological complications of infection by the Zika virus: a new emerging neurotropic virus. Rev Neurol 62: 317-328.

42. Frank C, Faber M, Stark K (2016) Causal or not: applying the Bradford Hill aspects of evidence to the association between Zika virus and microcephaly. EMBO Mol Med.

43. Teissier N, Fallet-Bianco C, Delezoide AL, Laquerrière A, Marcorelles P, Khung Savatovsky S, Nardelli J, Cipriani S, Csaba Z, Picone O, Golden JA, Van Den Abbeele T, Gressens P, Adle-Biassette H (2014) Cytomegalovirus-induced brain malformations in fetuses. J Neuropathol Exp Neurol 73: 143158.

44. Mlakar J, Korva M, Tul N, Popović M, Poljšak-Prijatelj M, Mraz J, Kolenc M, Resman Rus K, Vesnaver Vipotnik T, Fabjan Vodušek V, Vizjak A, Pižem J, Petrovec M, Avšič Županc (2016) Zika Virus Associated with Microcephaly. N Engl J Med.

45. Phuc HK, Andreasen MH, Burton RS, Vass C, Epton MJ, Pape G, Fu G, Condon KC, Scaife S, Donnelly CA, Coleman PG, White-Cooper H, Alphey L (2007) Late-acting dominant lethal genetic systems and mosquito control. BMC Biol 5: 11.

46. Ye YH, Carrasco AM, Frentiu FD, Chenoweth SF, Beebe NW, van den Hurk AF, Simmons CP, O'Neill SL, McGraw EA (2015) Wolbachia Reduces the Transmission Potential of Dengue-Infected Aedes aegypti. PLoS Negl Trop Dis 9: e0003894.

47. Dutra HL, Dos Santos LM, Caragata EP, Silva JB, Villela DA, Maciel-de-Freitas R, Moreira LA (2015) From lab to field: the influence of urban landscapes on the invasive potential of
Wolbachia in Brazilian Aedes aegypti mosquitoes. PLoS Negl Trop Dis Apr 9: e0003689.

48. Kelvin AA, Banner D, Pamplona L, Alencar C, Rubino S, Heukelbach J (2016) ZIKATracker: A mobile App for reporting cases of ZIKV worldwide. J Infect Dev Ctries 10: 113-115. doi:10.3855/jidc.8248.

49. Centers for Disease Control and Prevention (2016) CDC 24/7: Saving Lives, Protecting People, 2016. Available: http://www.cdc.gov/zika/. Accessed 21 March 2016.

50. Pan American Health Organization (PAHO) (2016) PAHO, 2016. Available: http://www.paho.org/hq/index.php?option=com_content\&vie $\mathrm{w}=$ article \&id $=11585 \&$ Itemid $=41688 \&$ lang $=$ en. Accessed 21 March 2016.

51. European Centre for Disease Prevention and Control (ECDC) (2016) Zika Outbreaks in the Americas and the Pacific. Available: http://ecdc.europa.eu/en/Pages/home.aspx. Accessed 21 March 2016.

52. Specialized Information Services (SIS) (2016) SIS: Disaster Information Management Research Centre, 2016. Available: https://sis.nlm.nih.gov/dimrc/zikavirus.html. Accessed 21 March 2016.

53. Medscape News and Perspective. 2016. Available: http://www.medscape.com/resource/zika-virus. Accessed 21 March 2016.

\section{Corresponding author}

Mohammed N. Al-Ahdal, PhD

Department of Infection and Immunity, Research Center, King Faisal Specialist Hospital \& Research Center, Riyadh, Saudi Arabia

Phone: 966114427867

Fax: 966114424519

Email: ahdal@kfshrc.edu.sa

Conflict of interests: No conflict of interests is declared. 